\title{
ANALISIS FAKTOR-FAKTOR YANG MEMPENGARUHI PERTUMBUHAN EKONOMI DI KABUPATEN DAN KOTA PROPINSI SUMATERA UTARA
}

\author{
Ramadona Simbolon \\ Dosen FE UISU \\ Abstrak
}

Penelitian ini bertujuan untuk menguji faktor pendapatan asli daerah (PAD), dana alokasi umum (DAU) dan dana alokasi khusus (DAK), dana bagi hasil (DBH), Investasi Daerah, Belanja Pengawai dan Belanja Modal yang paling mempengaruhi pertumbuhan ekonomi di Kabupaten dan Kota di Propinsi Sumatera Utara dan Untuk menguji pengaruh pendapatan asli daerah (PAD), dana alokasi umum (DAU) dan dana alokasi khusus (DAK), dana bagi hasil (DBH), Investasi Daerah, Belanja Pengawai dan Belanja Modal terhadap Pertumbuhan Ekonomi.

Pengujian hipotesis diuji dengan menggunakan derajat signifikan $5 \%$. Populasi terdiri dari 33 Kabupaten/Kota Propinsi Sumatera Utara. Metode pengambilan sampel menggunakan purpossive sampling. Jumlah sampel dalam penelitian ini adalah sebanyak 22 Kabupaten/Kota Propinsi Sumatera Utara dengan periode pengamatan 4 (empat) tahun yaitu periode 2005-2008. Pengujian hipotesis dilakukan dengan menggunakan analisis faktor dan analisis regresi berganda.

Hasil penelitian menunjukkan bahwa DAK, DAU, BP dan BM dapat digunakan sebagai faktor pembentuk Pertumbuhan Ekonomi sedangkan PAD, DHP dan ID tidak dapat digunakan sebagai faktor pembentuk Pertumbuhan Ekonomi. Hasil penelitian juga menunjukkan bahwa DAK, DAU, BP dan BM secara simultan berpengaruh terhadap Pertumbuhan Ekonomi sedangkan secara parsial hanya DAK, DAU dan BP yang berpengaruh terhadap Pertumbuhan Ekonomi.

Kata kunci : Pendapatan Asli Daerah, Dana Alokasi Umum, Dana Alokasi Khusus, Dana Bagi Hasil, Investasi Daerah, Belanja Pegawai dan Belanja Modal Terhadap Pertumbuhan Ekonomi 


\section{RAMADONA SIMBOLON}

\section{PENDAHULUAN}

\section{Latar Belakang Penelitian}

Indonesia sebagai suatu negara yang sedang berkembang, sejak tahun 1969 dengan giat melaksanakan pembangunan secara berencana dan bertahap, tanpa mengabaikan usaha pemerataan dan kestabilan. Pembangunan nasional mengusahakan tercapainya Pertumbuhan Ekonomi yang cukup tinggi, yang pada akhirnya memungkinkan terwujudnya peningkatan taraf hidup dan kesejahteraan seluruh rakyat. Perkembangan Pertumbuhan Ekonomi di Indonesia mengalami perubahan yang fluktuatif dari tahun ke tahun.

Perkembangan Pertumbuhan Ekonomi di Indonesia menunjukkan perkembangan yang positif dari tahun 1999-2007. Pada tahun 1998 menunjukkan penurunan Pertumbuhan Ekonomi yaitu $-13,12 \%$, hal ini disebabkan karena krisis ekonomi yang terjadi pada pertengahan tahun 1997, yang berlanjut menjadi krisis multidimensi, sehingga membawa dampak pada Pertumbuhan Ekonomi di Indonesia, kemudian pada tahun-tahun berikutnya perekonomian nasional Indonesia mengalami pemulihan, meskipun jika dibandingkan dengan negara-negara Asia lainnya yang mengalami krisis serupa, proses pemulihan ekonomi di Indonesia sedikit lebih lambat.

Otonomi daerah merupakan solusi alternatif dalam mengatasi berbagai permasalahan di atas. Indonesia memasuki era otonomi daerah sejak tanggal 1 Januari 2001. Pelaksanaan otonomi daerah mengacu pada UU nomor 32 tahun 2004 mengenai pembagian kewenangan dan fungsi (power sharing) antara pemerintah pusat dan daerah dan UU nomor 33 tahun 2004 mengenai perimbangan keuangan pusat dan daerah yaitu pengaturan pembagian sumber-sumber daya keuangan (financial sharing) antara pusat-daerah sebagai konsekuensi dari adanya pembagian kewenangan tersebut. Kondisi ini membawa implikasi pada pelimpahan kewenangan antara pusat dan daerah dalam berbagai bidang. Dengan adanya otonomi daerah, maka terjadi desentralisasi yang menyangkut pengelolaan keuangan daerah, perencanaan ekonomi (termasuk menyusun program-program pembangunan daerah) dan perencanaan lainnya yang dilimpahkan dari pusat ke daerah. Pemerintah daerah memiliki kewenangan yang luas dalam mengatur sumber daya yang ada untuk meningkatkan kemajuan dan kemakmuran masyarakat.

Berdasarakan undang-undang Nomor: 32 Tahun 2004 tentang Pemerintahan Daerah, Pasal 15 ayat 1, menyatakan : Hubungan dalam bidang keuangan antara Pemerintah Pusat dan Pemerintahan Daerah meliputi : a) pemberian sumber-sumber keuangan untuk menyelenggarakan urusan pemerintahan yang menjadi kewenangan pemerintahan daerah ; b) pengalokasian dana perimbangan kepada pemerintahan daerah; dan c) pemberian pinjaman dan/atau hibah kepada pemerintah daerah. Undang-undang tersebut mengandung pengertian bahwa kepada daerah diberikan kewenangan untuk memanfaatkan sumber keuangan sendiri yaitu Pendapatan Asli 


\section{RAMADONA SIMBOLON}

Daerah (PAD), dan Dana Alokasi Khusus (DAK). Berdasarkan hal tersebut, salah satu indikator penting dari kewenangan keuangan daerah adalah otonomi fiskal daerah. Otonomi fiskal (Pendapatan Asli Daerah) memberikan gambaran kemandirian atau kemampuan suatu daerah dalam berotonomi.

Kondisi ini membawa implikasi pada pelimpahan kewenangan antara pusat dan daerah dalam berbagai bidang. Dengan adanya otonomi daerah, maka terjadi desentralisasi yang menyangkut pengelolaan keuangan daerah, perencanaan ekonomi (termasuk menyusun program-program pembangunan daerah) dan perencanaan lainnya yang dilimpahkan dari pusat ke daerah. Pemerintah daerah memiliki kewenangan yang luas dalam mengatur sumber daya yang ada untuk meningkatkan kemajuan dan kemakmuran masyarakat.

Di era otonomi daerah, pemerintah daerah diharapkan mampu melakukan alokasi sumber daya yang efisien. Kemampuan daerah untuk mengelola sumber daya secara efisien tercermin dari kebijakan yang diterapkan oleh pemerintah daerah selaku perencana, dimana hal ini akan membawa dampak pada keberhasilan ekonomi daerah secara optimal. Dengan adanya otonomi, setiap daerah diharapkan mampu mengembangkan potensi baik sumber daya alam, sumber daya manusia, budaya untuk meningkatkan kemakmuran bagi seluruh masyarakat daerah. Dengan kata lain, bahwa otonomi daerah menuntut adanya suatu kemandirian daerah di dalam berbagai aspek terutama aspek perencanaan, keuangan, dan pelaksanaan.

Pada beberapa tahun terakhir perekonomian di Indonesia belum menunjukkan pemulihan yang berarti setelah terjadi krisis ekonomi tahun 1997-1998 yang berimbas ke daerah. Beberapa indikator ekonomi yang mendukung ekonomi tersebut antara lain pertumbuhan ekonomi yang belum optimal, tingkat penggangguran dan investasi yang belum maksimal.

Dari data yang diperoleh Badan Pusat Stastistik, pertumbuhan ekonomi secara nasional meningkat sebesar 6,10 \% pada tahun 2008 sedangkan pertumbuhan ekonomi daerah khususnya di Sumatera Utara sebesar 6,39 \% pada tahun 2008. Peneliti melihat suatu fenomena dalam kurun waktu 2004- 2008 yang cenderung meningkat dari tahun ke tahun. Sumatera Utara adalah salah satu propinsi yang menyumbangkan pajak dari sektor perkebunan yang terbesar di Indonesia selain Propinsi Riau tentunya. Propinsi Sumatera Utara pun dalam beberapa tahun belakangan ini telah memekarkan daerahnya menjadi beberapa kabupaten baru seperti Kabupaten Serdang Bedagai, Kabupaten Batubara, Kabupaten Phakpak Barat, yang menunjukkan bahwa di Sumatera Utara masih terdapat potensi penerimaan Pendapatan Asli Daerah yang masih dapat dikembangkan lagi. Beberapa daerah itu sedang berada dalam tahap pengembangan daerah, dan hal ini amat nampak dari perkembangan Kabupaten Serdang Bedagai yang menunjukkan perkembangan yang paling menonjol dibandingkan dengan daerah pemekaran lainnya.

Penelitian ini dilakukan karena adanya ketidakkonsistenan hasil-hasil penelitian terdahulu mengenai faktor-faktor yang mempengaruhi pertumbuhan ekonomi daerah. Ketidakkonsistenan ini nampak dari penelitian yang dilakukan oleh 


\section{RAMADONA SIMBOLON}

Fitriyanti dan Pratolo (2009). Penelitian yang dilakukan oleh Fitriyanti dan Pratolo ini ingin melihat pengaruh Pendapatan Asli Daerah dan Belanja Pembangunan Terhadap Rasio Kemandirian dan Pertumbuhan Ekonomi. Hasil penelitian ini menyebutkan bahwa terdapat pengaruh yang signifikan antara Pendapatan Asli Daerah dan Belanja Pembangunan terhadap kemandirian daerah, serta menyimpulkan bahwasannya Pendapatan Asli Daerah dan Belanja Pembangunan tidak berpengaruh secara signifikan terhadap Pertumbuhan Ekonomi. Namun, hasil penelitian yang dilakukan oleh Fitriyanti dan Pratolo (2009) ini memiliki hasil yang cukup berbeda dengan penelitian yang dilakukan oleh Ardi Hamzah (2009). Peneltian yang dilakukan oleh Ardi Hamzah (2009) ingin melihat pengaruh antara Pendapatan Asli Daerah (PAD), Dana Perimbangan, dan Belanja Publik terhadap Pertumbuhan Ekonomi, Kemiskinan dan Pengangguran. Hasil penelitian ini menyebutkan bahwa baik secara langsung maupun tidak langsung Pendapatan Asli Daerah (PAD), Dana Perimbangan dan Belanja Publik tidak memiliki pengaruh yang signifikan terhadap Pertumbuhan Ekonomi.

Penelitian ini merupakan replikasi dari penelitian yang telah dilakukan oleh Fitriyanti dan Pratolo (2009) dengan judul "Pengaruh Pendapatan Asli Daerah dan Belanja Pembangunan Terhadap Rasio Kemandirian dan Pertumbuhan Ekonomi. Penelitian yang dilakukan oleh Fitriyanti dan Pratolo menggunakan dua variabel independen yaitu Belanja Pembangunan dan Pendapatan Asli Daerah (PAD) serta satu variabel dependen yaitu Pertumbuhan Ekonomi dan variabel intervening yaitu Kemandirian Daerah.

Berdasarkan dari penelitian yang dilakukan oleh Fitriyanti dan Pratolo ini, maka penulis melakukan penelitian lanjutan dengan menambahkan variabel independen yaitu variabel DAU,DAK, Bagi Hasil Pajak dan Belanja Pegawai dengan lokasi penelitian yang berbeda dan tahun penelitian yang berbeda pula. Pendapatan per kapita itu sendiri merupakan indikator kenaikan pertumbuhan ekonomi di suatu daerah. Penulis ingin melihat pengaruh dari variabel-variabel tersebut terhadap Pertumbuhan Ekonomi daerah di 15 Kabupaten dan 7 Kota di Sumatera Utara pada tahun-tahun amatan antara 2004-2008.

Fenomena yang selama ini ada di daerah adalah otonomi daerah yang berjalan belum maksimal, dari data-data yang diperoleh dari dan beberapa literatur yang ada, menunjukkan bahwa otonomi daerah selama ini belum berjalan secara maksimal. Beberapa rencana yang telah disusun oleh pemerintah daerah, hampir sebagian besar belum terealisasi dengan baik. Potensi-potensi yang ada selama ini juga belum sepenuhnya dapat tereksploitasi dengan baik dan benar oleh Pemerintah Kota dan Kabupaten. Atas hal tersebut peneliti berusaha meneliti tentang: "Faktor-faktor yang mempengaruhi Pertumbuhan Ekonomi pada Kabupaten dan Kota Se Sumatera Utara." 


\section{RAMADONA SIMBOLON}

\section{Perumusan Masalah}

Berdasarkan latar belakang yang telah diuraikan di atas, maka peneliti merumuskan masalah yaitu :

1. Faktor-faktor PAD, DAU, DAK, DBH, Investasi Daerah, Belanja Pegawai dan Belanja Modal manakah yang dominan mempengaruhi pertumbuhan ekonomi pada Kabupaten dan Kota di Propinsi Sumatera Utara?."

2. Apakah pendapatan asli daerah (PAD), dana alokasi umum (DAU) dan dana alokasi khusus (DAK), dana bagi hasil (DBH), Investasi Daerah, Belanja Pengawai dan Belanja Modal berpengaruh terhadap Pertumbuhan Ekonomi?

\section{Tujuan Penelitian}

Berdasarkan latar belakang dan permasalahan yang telah dikemukakan sebelumnya, maka tujuan penelitian ini adalah untuk

1. Untuk menguji faktor PAD, DAU, DAK, DBH, Investasi Daerah, Belanja Pegawai dan Belanja Modal yang paling mempengaruhi pertumbuhan ekonomi di Kabupaten dan Kota di Propinsi Sumatera Utara.

2. Untuk menguji pengaruh pendapatan asli daerah (PAD), dana alokasi umum (DAU) dan dana alokasi khusus (DAK), dana bagi hasil (DBH), Investasi Daerah, Belanja Pengawai dan Belanja Modal terhadap Pertumbuhan Ekonomi.

\section{Manfaat Penelitian}

Penelitian ini diharapkan memberi manfaat yaitu :

1. Bagi peneliti menambah wawasan dan pengetahuan dalam menganalisis faktorfaktor PAD, DAU, DAK, DBH, ID, BP dan BM yang mempengaruhi Pertumbuhan Ekonomi di kab/kota se Sumatera Utara.

2. Bagi Pemerintah daerah untuk menganalisis potensi daerahnya dalam peningkatan Pertumbuhan Ekonomi Daerah yang terdapat di Kabupaten dan Kota yang berada di dalam Propinsi Sumatera Utara.

3. Bagi Peneliti selanjutnya untuk bahan referensi penelitian terutama pada bidang penelitian yang sejenis. 


\section{RAMADONA SIMBOLON}

\section{TINJAUAN PUSTAKA}

\section{Tinjauan Teoritis}

Pertumbuhan ekonomi adalah proses di mana terjadi kenaikan produk nasional bruto riel. Jadi perekonomian dikatakan tumbuh atau berkembang bila terjadi pertumbuahn output riel. Definisi pertumbuhan ekonomi yang lain adalah bahwa pertumbuhan ekonomi terjadi bila ada kenaikan taraf hidup diukur dengan output riel per kapita. Karena itu, pertumbuhan ekonomi terjadi bila tingkat kenaikan output riel total lebih besar daripada tingkat pertambahan penduduk. Ada beberapa sumber strategis dan dominan yang menentukan pertumbuhan ekonomi tergantung pada bagaimana kita mengklasifikasikan. Salah satu klasifikasinya adalah faktor-faktor fisik dan faktor-faktor manajemen yang mempengaruhi penggunaan sumber-sumber tersebut. Meskipun dipunyai sumber dominan untuk pertumbuhan yang kuantitasnya cukup banyak serta dengan kualitas cukup tinggi tetapi bila manajemen penggunaannya tidak menunjang maka laju pertumbuhan ekonomi akan rendah.

\section{Pendapatan Asli Daerah (PAD)}

Menutut Bastian (2001:49), penerimaan Pendapatan Asli Daerah merupakan akumulasi dari Pos Penerimaan Pajak yang berisi Pajak Daerah dan Pos Retribusi Daerah, Pos Penerimaan Non Pajak yang berisi hasil perusahaan milik daerah, Pos Penerimaan Investasi serta Pengelolaan Sumber Daya Alam.

Pendapatan Asli Daerah (PAD) merupakan semua penerimaan daerah yang berasal dari sumber ekonomi asli daerah. Identifikasi sumber Pendapatan Asli Daerah adalah : meneliti, menentukan dan menetapkan mana sesungguhnya yang menjadi sumber Pendapatan Asli Daerah dengan cara meneliti dan mengusahakan serta mengelola sumber pendapatan tersebut dengan benar sehingga memberikan hasil yang maksimal. Sedangkan Pendapatan Asli Daerah adalah pendapatan yang diperoleh dari sumber-sumber pendapatan daerah dan dikelola sendiri oleh Pemerintah Daerah.

Berdasarkan UU nomor 32 tahun 2004 pasal 79 disebutkan bahwa pendapatan asli daerah terdiri dari hasil pajak daerah, hasil retribusi daerah, hasil perusahaan milik daerah, dan hasil pengelolaan milik daerah yang dipisahkan, lain-lain pendapatan asli daerah yang sah.

\section{Dana Alokasi Umum}

Dana Alokasi Umum adalah dana yang bersumber dari pendapatan APBN yang dialokasikan bertujuan untuk Pemerataan Kemampuan keuangan antar daerah melalui penerapan formula yang mempertimbangkan kebutuhan Belanja Pegawai, Kebutuhan Fiskal dan Potensi Daerah. Komponen variabel kebutuhan fiskal (fiscal needs) yang digunakan untuk pendekatan perhitungan DAU untuk kebutuhan daerah terdiri dari: Indeks Jumlah Penduduk, Indeks Luas wilayah, Indeks Pembangunan Manusia (IPM), Indeks Kemahalan Konstruksi (IKK), dan Indeks Produk Domestik 


\section{RAMADONA SIMBOLON}

Regional Bruto (PDRB) per kapita. Sedangkan Kapasitas Fiskal dicerminkan dari Pendapatan Asli Daerah, Dana Bagi Hasil Pajak dan Sumber Daya Alam (Fhino \& Priyo, 2009).

Pemerintah pusat dalam undang-undang Nomor. 33 tahun 2004 tentang perimbangan keuangan antara pemerintah pusat dan pemerintah daerah, mengalokasikan sejumlah dana dari APBN sebagai dana perimbangan. Dana perimbangan terdiri dari Dana Alokasi Umum (DAU), Dana Alokasi Khusus (DAK) dan Dana Bagi Hasil (DBH). Dana Alokasi Umum adalah dana yang bersumber dari pendapatan APBN yang dialokasikan dengan tujuan pemerataan kemampuan keuangan antar daerah untuk mendanai kebutuhan daerah dalam rangka pelaksanaan desentralisasi. Dana Alokasi Khusus adalah dana yang bersumber dari pendapatan APBN yang dialokasikan untuk daerah tertentu dengan tujuan untuk membantu mendanai kegiatan khusus yang merupakan urusan daerah sesuai dengan prioritas nasional. Sedangkan Dana Bagi Hasil adalah dana yang bersumber dari pendapatan APBN yang dialokasikan kepada daerah berdasarkan angka persentase untuk mendanai kebutuhan daerah dalam rangka pelaksanaan desentralisasi.

\section{Dana Alokasi Khusus}

Berdasarkan Peraturan Pemerintah Nomor 55 tahun 2005 tentang Dana perimbangan bahwa Dana Alokasi Khusus untuk mendanai kegiatan khusus yang menjadi urusan daerah dan merupakan prioritas nasional, sesuai dengan fungsi yang merupakan perwujudan tugas ke pemerintahan dibidang tertentu khususnya dalam upaya pemenuhan kebutuhan sarana dan prasarana pelayanan dasar masyarakat.

Berdasarkan Peraturan Menteri Dalam Negeri Nomor 30 Tahun 2007 Penggunaan Dana perimbangan Khususnya Dana Alokasi Khusus (DAK) dialokasikan kepada daerah tertentu untuk mendanai kebutuhan fisik, sarana dan prasarana dasar yang menjadi urusan daerah antara lain program dan kegiatan pendidikan, kesehatan dan lain-lain sesuai dengan petunjuk teknis yang ditetapkan oleh menteri teknis terkait sesuai dengan peraturan peraturan perundang-undangan.

Selain Dana Bagi Hasil dan Dana alokasi Umum kepada Daerah juga disediakan Dana Alokasi Khusus (DAK) yang di golongkan kedalam bantuan yang bersifat specific grant. Pada awalnya DAK yang disediakan bagi daerah seluruhnya bersumber dari dana reboisasi yang dialokasi sebesar $40 \%$ dari penerimaannya. Namun dari tahun 2003 selain untuk membiayai kegiatan rebiosasi disaerah penghasil, DAK diberikan juga dalam DAK non DR yang disediakan bagi daerah tertentu untuk mendanai kebutuhan khusus seperti; (a) Kebutuhan yang tidak dapat diperkirakan secara umum dengan menggunakan rumus alokasi umumdan/atau (b) kebutuhan yang merupakan komitmen atau prioritas nasional. Dalam perkembangannya, realisasi DAK senantiasa menunjukkan kecenderungan yang meningkat dari tahun ke tahun. 


\section{RAMADONA SIMBOLON}

\section{Dana Bagi Hasil (DBH)}

Dana Bagi Hasil adalah dana yang bersumber dari pendapatan APBN yang dialokasikan kepada daerah berdasarkan angka persentase untuk mendanai kebutuhan daerah dalam rangka pelaksanaan Desentralisasi. Dana Bagi Hasil (DBH) merupakan dana bagian daerah yang bersumber dari penerimaan perpajakan dan penerimaan sumber daya alam.

Rincian Dana Bagi Hasil terdiri dari Dana Bagi Hasil Perpajakan yaitu Dana Bagi Hasil Pajak Bumi dan Bangunan (DBH-PBB), Dana Bagi Hasil Bea Perolehan Hak atas Tanah dan Bangunan (DBHB PHTB), Pajak Penghasilan (PPh) Pasal 25 dan Pasal 29 Wajib Pajak Orang Pribadi Dalam Negeri dan PPh Pasal 21. Sedangkan Dana Bagi Hasil dari Sumber Daya Alam (DBH dari SDA) teridir dari Dana Bagi Hasil Sumber Daya Alam kehutanan (DBH-SDA Kehutanan), Dana Bagi Hasil Sumber Daya Alam Pertambangan Umum, Dana Bagi Hasil SDA perikanan adalah sebagal berlkut, Dana Bagi Hasil pertambangan minyak bumi, Dana Bagi Hasil pertambangan gas bumi, Dana Bagi Hasil SDA pertambangan panas bumi

\section{Investasi Daerah}

Berhasil tidaknya pelaksanaan Otonomi Daerah tidak saja tergantung kepada kemauan kuat aparatur Pemerintahan Pusat yang diharapkan menyerahkan sebagian kewenangannya kepada aparatur pemerintahan di daerah, melainkan terletak pada keprakarsaan dan kesungguhan aparatur di daerah sendiri untuk memberi arti dan meningkatkan kualitas kemandirian daerah itu sendiri. Bahkan, sejatinya kebijakan otonomi daerah itu harus pula diartikan terletak pada kemandirian, keprakarsaan, dan kreatifitas warga masyarakat daerah sebagai keseluruhan. Artinya, otonomi daerah itu bermakna ganda, yaitu otonomi Pemerintah Daerah dari Pemerintah Pusat, dan juga otonomi masyarakat di daerah itu dari Pemerintah Daerahnya. Karena itu, agenda otonomi daerah haruslah diimbangi dan dibarengi oleh partisipasi dari bawah, baik dalam arti formal oleh institusi pemerintahan di daerah maupun dalam arti substansial oleh para pelaku ekonomi dan institusi masyarakat di tingkat lokal.

\section{Belanja Daerah atau Pengeluaran Daerah (Local Expenditure)}

Belanja daerah adalah semua pengeluaran pemerintah daerah pada suatu periode Anggaran (Abdul Halim, 2002:52). Anggaran Pendapatan dan Belanja Daerah terdiri dari dua komponen utama yaitu: belanja langsung dan belanja tidak langsung.

Jenis belanja langsung dapat diukur dengan hasil dari suatu program dan kegiatan yang dianggarkan, termasuk efisiensi dalam pencapaian keluaran dan hasil tersebut yaitu belanja pegawai untuk membayar honorarium/upah kerja, belanja barang dan jasa dan belanja modal.

Jenis belanja yang tidak langsung dapat diukur dengan keluaran dan hasil yang diharapkan dari suatu program dan kegiatan seperti belanja pegawai untuk membayar gaji dan tunjangan PNS, belanja bunga, belanja subsidi, belanja hibah, 


\section{RAMADONA SIMBOLON}

belanja bantuan sosial, belanja bagi hasil, bantuan keuangan dan belanja tidak terduga.

\section{Belanja Modal}

Belanja Modal sebagaimana dimaksud dalam pasal 50 huruf c Permendagri No 59 Tahun 2007 tentang perubahan Permendagri Nomor 13/2006 Tentang pengelolaan Keuangan Daerah digunakan untuk pengeluaran yang dilakukan dalam rangka pengadaan asset tetap berwujud yang mempunyai nilai manfaat lebih dari 12 (dua belas) bulan untuk digunakan dalam kegiatan pemerintahan. Sedangkan menurut PSAP Nomor 2, Belanja Modal adalah pengeluaran anggaran untuk perolehan asset tetap dan asset lainnya yang memberi manfaat lebih dari satu periode akuntansi. Selanjutnya pada pasal 53 ayat 2 Permendagri Nomor 59 Tahun 2007 ditentuka bahwa nilai asset tetap berwujud yang dianggarkan dalam belanja modal sebesar harga beli/bangun asset ditambah seluruh belanja yang terkait dengan pengadaan/ pembangunan asset sampai asset tersebut siap digunakan. Kemudian pada pasal 53 ayat 4 Permendagri Nomor 59 Tahun 2007 disebutkan bahwa Kepala Daerah menetapkan batas minimal kapitalisasi sebagai dasar pembebanan belanja modal selain memenuhi batas minimal juga pengeluaran anggaran untuk belanja barang tersebut harus memberi manfaat lebih satu periode akuntansi bersifat tidak rutin. Ketentuan hal ini sejalan dengan PP 24 Tahun 2004 tentang Standar Akuntansi Pemerintahan khususnya PSAP no 7, yang mengatur tentang akuntansi asset tetap. 


\section{Kerangka Konsep}

Kerangka konsep untuk melihat Faktor-faktor yang mempengaruhi pertumbuhan Ekonomi daerah adalah seperti ditunjukkan oleh gambar berikut.

Faktor -Faktor

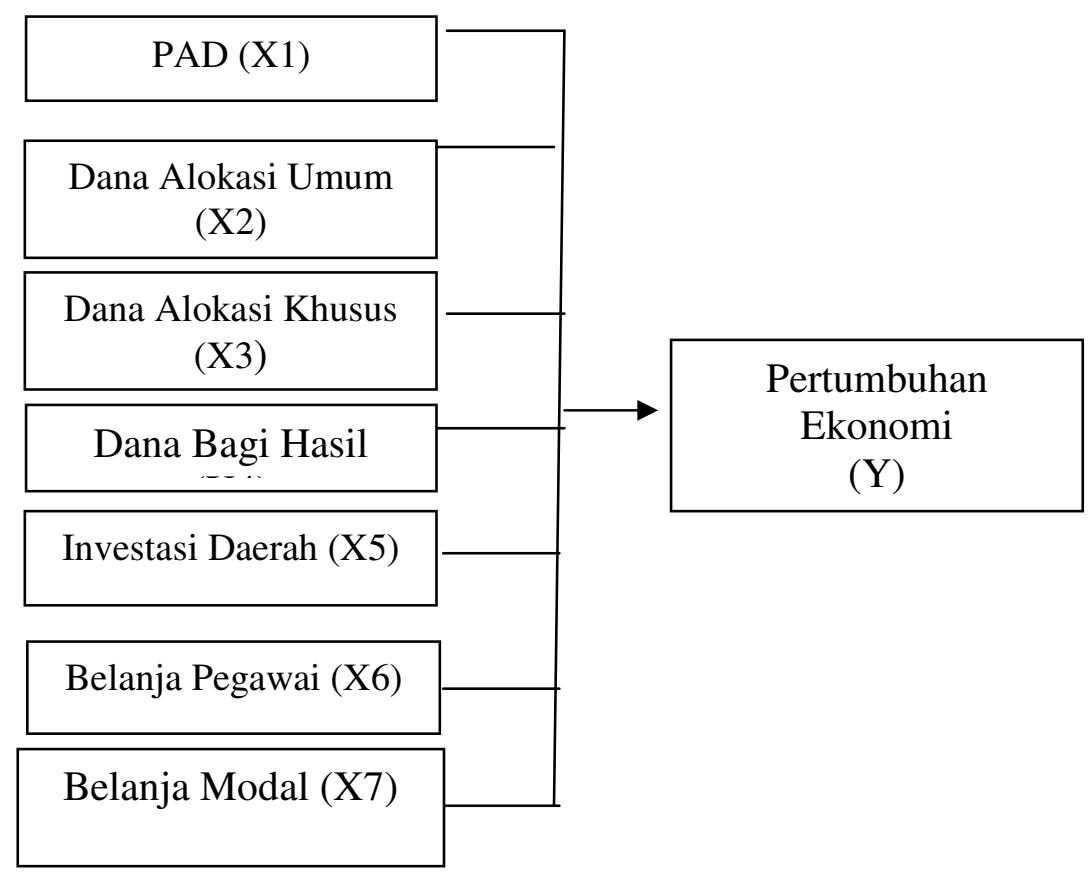

Gambar 3.1.

Kerangka Konseptual

\subsection{Hipotesis Penelitian}

Hipotesis yang dirumuskan dalam penelitian ini adalah

H1 : Pendapatan Asli Daerah (PAD), Dana Alokasi Umum (DAU), Dana Alokasi Khusus (DAK), Bagi Hasil Pajak (BHP), Investasi Daerah, Belanja Pegawai, dan Belanja Modal merupakan faktor-faktor yang dominan mempengaruhi Pertumbuhan Ekonomi di Kabupaten dan Kota Propinsi Sumatera Utara.

H2 : Pendapatan Asli Daerah (PAD), Dana Alokasi Umum (DAU), Dana Alokasi Khusus (DAK), Bagi Hasil Pajak (BHP), Investasi Daerah, Belanja Pegawai, dan Belanja Modal berpengaruh terhadap Pertumbuhan Ekonomi di Kabupaten dan Kota Propinsi Sumatera Utara. 


\section{RAMADONA SIMBOLON}

\section{METODE PENELITIAN}

\section{Jenis Penelitian}

Jenis penelitian ini merupakan penelitian kausal (causal), Umar (2008) menyebutkan desain kausal berguna untuk menganalisis bagaimana suatu variabel mempengaruhi variabel lain, dan juga berguna pada penelitian yang bersifat eksperimen, dimana variabel independennya diperlakukan secara terkendali oleh peneliti untuk melihat dampaknya pada variabel dependennya secara langsung.

Peneliti menggunakan desain penelitian ini untuk memberikan bukti empiris dan menganalisis Pendapatan Asli Daerah (PAD), Dana Alokasi Umum, Dana Alokasi Khusus, BHP, Investasi Daerah, Belanja Pegawai dan Belanja Modal terhadap Pertumbuhan Ekonomi di Kabupaten dan Kota Propinsi Sumatera Utara.

\section{Lokasi dan Waktu Penelitian}

Lokasi penelitian pada Kabupaten dan Kota di Provinsi Sumatera Utara dalam kurun waktu antara tahun 2004-2008. Sedangkan rencana waktu penelitian yakni selama bulan Oktober 2010 - Februari 2011.

\section{Populasi dan Sampel Penelitian}

Populasi dalam penelitian ini adalah seluruh kabupaten dan kota di Propinsi Sumatera Utara pada tahun 2004-2008 yang berjumlah 33 populasi. Teknik pengambilan sampel dalam penelitian ini adalah Purposive Sampling yang merupakan teknik penentuan sampel anggota populasi dengan pertimbangan atau kriteria tertentu (Sugiyono, 2007:78). Kriteria penentuan sampel dalam penelitian ini adalah kabupaten dan kota di Propinsi Sumatera Utara yang rutin menerbitkan laporan keuangan dari tahun 2004-2008. Jumlah sampel penelitian ini sebanyak 22 sampel yang terdiri dari 15 kabupaten dan 7 kota.

\section{Metode Pengumpulan Data}

Data yang dipergunakan pada penelitian ini adalah data sekunder. Data-data tersebut adalah berupa data Pendapatan Asli Daerah, Dana Alokasi Khusus, Dana Alokasi Umum, Investasi Daerah, Belanja Modal dan Belanja Pegawai yang diperoleh dari Biro Pusat Statistik (BPS) serta didownload dari internet melalui www.bps.go.id. 


\section{RAMADONA SIMBOLON}

\section{Definisi Operasional dan Pengukuran Variabel}

\section{Pendapatan Asli Daerah (X1)}

Pendapatan Asli Daerah (PAD) merupakan realisasi anggaran penerimaan asli daerah yang bersumber dari pajak daerah, retribusi daerah, pembagian hasil BUMD dan lain lain..PAD yang digunakan merupakan realisasi pendapatan daerah yang diterima kab/kota per tahun (dalam Rupiah).

2. Dana Alokasi Umum (X2)

Dana Alokasi Umum merupakan transfer yang bersifat umum dari pemerintah pusat ke pemerintah daerah yang dialokasikan dengan tujuan pemerataan keuangan antar daerah untuk membiayai kebutuhan pengeluarannya. DAU yang digunakan adalah realisasi DAU yang diterima Kab/kota per tahun (dalam Rupiah)..

3. Dana Alokasi Khusus (X3)

Dana Alokasi Khusus merupakan transfer yang bersifat khusus dari pemerintah pusat ke pemerintah derah untuk mengatasi kepentingan horizontal dengan tujuan pemertaan kemampuan keuangan antar daerah untuk membiayai pengeluaran pemerintah. DAK yang digunakan merupakan realisasi DAK diterima daerah kabupaten/kota per tahun (dalam Rupiah).

4. Dana Bagi Hasil (X4)

Dana Bagi Hasil merupakan dana bagian daerah yang bersumber dari penerimaan perpajakan dan penerimaan sumber daya alam di daerah tersebut. DBH yang digunakan merupakan realisasi Dana Bagi hasil yang diterima Kab/kota per tahun (dalam Rupiah).

5. Investasi Daerah (X5).

Investasi Daerah merupakan penanaman modal yang dananya berasal dari daerah itu sendiri. Investasi Daerah yang digunakan adalah realisasi Investasi daerah yang diterima kab/kota per tahun (dalam Rupiah).

6. Belanja Pegawai (X6)

Belanja pegawai yaitu merupakan belanja kompensasi, dalam bentuk gaji dan tunjangan, serta penghasilan lainnya yang diberikan kepada pegawai negeri sipil yang ditetapkan sesuai dengan ketentuan perundang-undangan. Belanja Pegawai yang digunakan realisasi pengeluaran belanja pegawai yang diterima kab/kota per tahun (dalam Rupiah).

7. Belanja Modal (X7)

Belanja Modal adalah pengeluaran yang dilakukan dalam rangka kegiatan, pengadaan, sarana dan prasarana fisik pembagunan dan peningkatan atas indikator kesehatan, pendidikan dan ekonomi. Belanja Modal yang digunakan adalah realisasi Belanja Modal pemerintah Kab/kota per tahun (dalam rupiah). 


\section{RAMADONA SIMBOLON}

\section{Tabel 4.2}

Definisi Operasional Variabel

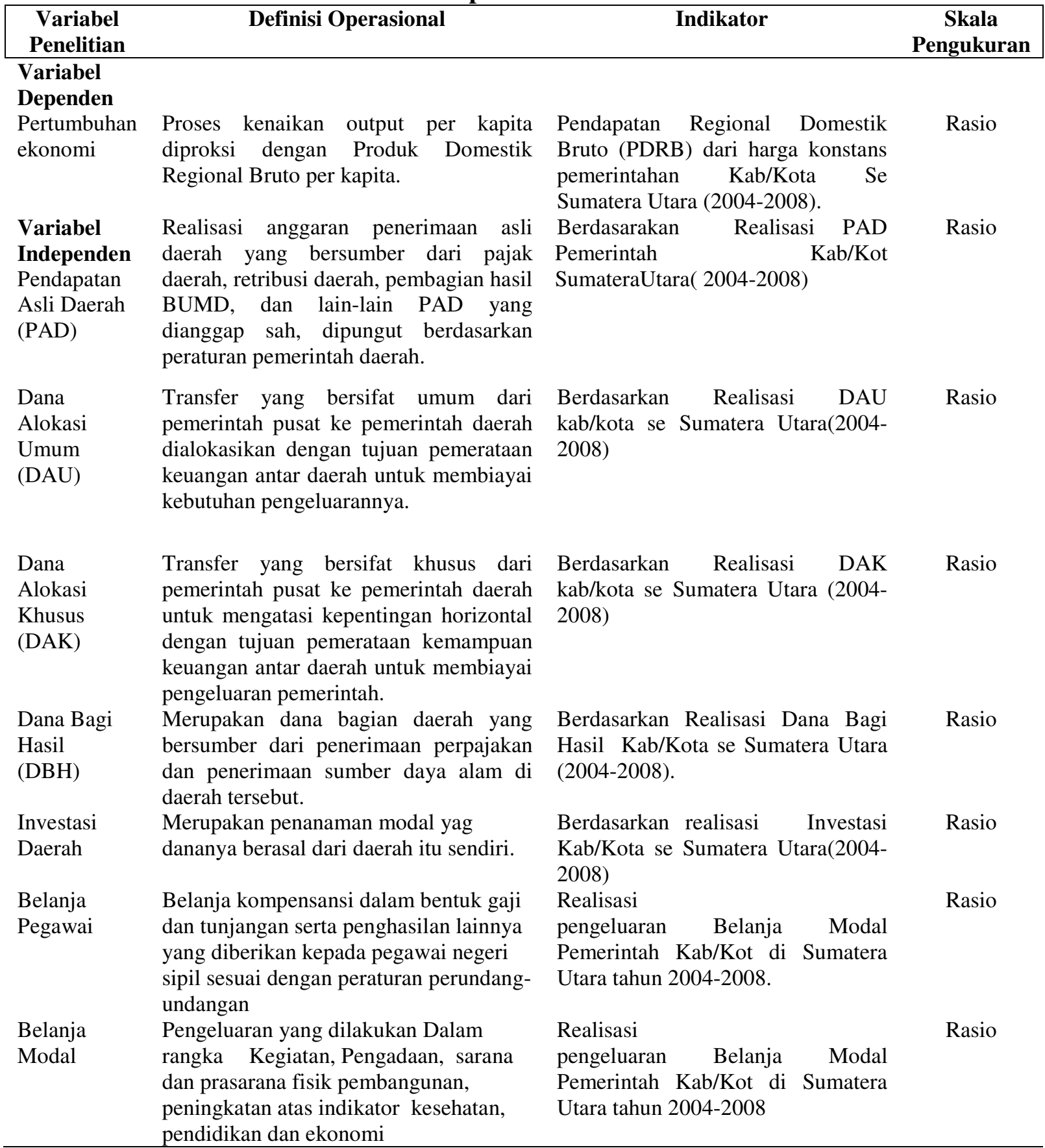




\section{RAMADONA SIMBOLON}

\subsection{Teknik Analisis Data}

\subsubsection{Analisis Faktor}

Pengolahan data analisis data dalam penelitian ini adalah analisa faktor dan Regresi Berganda. Analisa Faktor merupakan suatu teknik statistik multivariate yang digunakan untuk mengurangi (reduction) dan meringkas (summarization) semua variabel terikat dan ketergantungan.

Model analisis faktor dinyatakan dengan formula sebagai berikut :

Dimana

Model $1: \mathrm{Xi}=\mathrm{AiF} 1+\mathrm{AiF} 2+\mathrm{AiF} 3+\mathrm{AiF} 4+\mathrm{AiF} 5+\mathrm{AiF} 6+\mathrm{AiF} 7+\mathrm{e}$

$$
\begin{aligned}
& \mathrm{Xi}=\text { Pertumbuhan Ekonomi } \\
& \mathrm{F} 1=\text { Pendapatan Asli Daerah } \\
& \mathrm{F} 2=\text { Dana Alokasi Umum } \\
& \mathrm{F} 3=\text { Dana Alokasi Khusus } \\
& \mathrm{F} 4=\text { Dana Bagi Hasil } \\
& \mathrm{F} 5=\text { Investasi Daerah } \\
& \mathrm{F} 6=\text { Belanja Pegawai } \\
& \mathrm{F} 7=\text { Belanja Modal } \\
& \mathrm{e}=\text { Konstanta Error } \\
& \mathrm{Xi}=\text { Pertumbuhan Ekonomi } \\
& \mathrm{Ai}=\text { Konstanta }
\end{aligned}
$$

\subsubsection{Identifikasi Kecukupan Data}

Kecukupan data atau sampel dapat diidentifikasi melalui nilai Measure of Sampling Adequacy (MSA) dan Kaiser-Meyer-Olkin (KMO). Sekelompok data dikatakan memenuhi asumsi kecukupan data adalah jika nilai MSA dan KMO lebih besar daripada 0.5 (J.F.Hair,2006).

\subsubsection{Menilai Variabel yang Layak}

Variabel yang layak dapat diidentifikasi melalui Anti Image correlation. Jika menunjukkan kriteria angka MSA diatas 0,5 yang berarti variabel masih bisa diprediksi untuk dianalisa lebih lanjut (Santoso, 2002:101). Disamping itu dilihat dari nilai Barlett's Test menunjukkan nilai diatas 60,00 dengan nilai signifikansi 0,000, sehingga dapat disimpulkan bahwa instrument ini telah memenuhi syarat valid.

\subsubsection{Analisis Regresi Berganda}

Analisis regresi berganda bertujuan untuk mengetahui pengaruh variabel independen terhadap variabel dependen. Pengujian hipotesis dengan analisis regresi berganda dengan menggunakan uji $\mathrm{F}$ dan uji t.

\subsubsection{Uji F}

Priyatno (2008) menyebutkan uji simultan dengan uji $\mathrm{F}$ bertujuan untuk mengetahui apakah variabel independen secara bersama-sama berpengaruh signifikan terhadap variabel dependen. Dengan tingkat signifikansi dalam penelitian ini menggunakan alpha 5\% atau 0,05 hasil uji $\mathrm{F}$ menunjukan variabel independen secara 


\section{RAMADONA SIMBOLON}

bersama-sama berpengaruh terhadap variabel dependen, jika p-value (pada kolom sig.) lebih kecil dari level of significant yang ditentukan (sebesar $5 \%$ ).

1.6.2.2. Uji t

Pengujian hipotesis juga dilakukan dengan uji $t$, yaitu untuk melihat signifikansi pengaruh variabel bebas terhadap variabel terikat secara parsial :

a. Bila nilai sig. $<0.05$ berarti terdapat pengaruh yang signifikan variabel independen terhadap variabel dependen.

b. Bila nilai sig. $>0.05$ berarti tidak terdapat pengaruh yang signifikan variabel independen terhadap variabel dependen.

\subsubsection{Uji koefisien determinan}

Koefisien determinasi $(\mathrm{R})$ bertujuan untuk melihat seberapa besar pengaruh variabel independen yang digunakan dalam penelitian mampu menjelaskan varinai total variabel dependen. Nilai koefisien determinasi antara 0 dan $1\left(0<R^{2}<1\right)$. N yang mendekati satu berarti variabel-variabel independen memberikan hampir semua informasi yang dibutuhkan untuk memprediksi variabel-variabel dependen.

\section{HASIL PENELITIAN DAN PEMBAHASAN}

Propinsi Sumatera Utara berada di bagian Barat Indonesia, terletak pada garis lintang $10^{0}-40^{\circ}$ Lintang Utara dan $98^{\circ}-1000^{\circ}$ Bujur Timur, dengan luas. Letak Propinsi ini sangat strategis karena berada pada jalur perdagangan internasional yang berdekatan dengan Malaysia dan Singapura.

Batas - batasnya:

a. Sebelah Utara berbatasan dengan Propinsi Nanggroe Aceh Darusalam.

b. Sebelah Timur dengan Malaysia di Selat Malaka.

c. Sebelah Selatan berbatasan dengan dengan Propinsi Riau dan Sumatera Barat.

d. Sebelah Barat berbatasan dengan Samudera Hindia.

\section{Pengujian Hipotesis}

Pengujian hipotesis dilakukan dengan menggunakan analisis faktor dan analisis regresi berganda. Ringkasan hasil pengujian hipotesis dengan menggunakan analisis faktor dapat dilihat pada Tabel berikut ini. 


\section{RAMADONA SIMBOLON}

Tabel 5.1. Uji Kecukupan Data

KMO and Bartlett's Test

\begin{tabular}{|c|c|c|}
\hline \multicolumn{2}{|c|}{$\begin{array}{l}\text { Kaiser-Meyer-Olkin Measure of Sampling } \\
\text { Adequacy. }\end{array}$} & .558 \\
\hline $\begin{array}{l}\text { Bartlett's Test of } \\
\text { Sphericity }\end{array}$ & $\begin{array}{l}\text { Approx. Chi-Square } \\
\text { df } \\
\text { Sig. }\end{array}$ & $\begin{array}{r}334.675 \\
21 \\
.000\end{array}$ \\
\hline
\end{tabular}

Dari hasil uji KMO Kaiser Meyer - Olkins diperoleh nilai Kaiser Meyer Olkins Measure of Sampling Adequacy pada kotak sebesar 0.558 diatas 0,5. Disamping itu dilihat dari nilai Barlett's Test menunjukkan nilai 334,675 dengan nilai signifikansi 0,000, sehingga dapat disimpulkan bahwa data variabel dan sampel sudah dapat dianalisis lebih lanjut.

Tabel. 5.2. Hasil Korelasi Faktor

15

Anti-image Matrices

\begin{tabular}{|c|r|r|r|r|r|r|r|}
\hline & \multicolumn{1}{|c|}{ PAD } & \multicolumn{1}{c|}{ DAU } & \multicolumn{1}{c|}{ DAK } & \multicolumn{1}{l|}{ BHP } & \multicolumn{1}{l|}{ ID } & \multicolumn{1}{l|}{ BP } & \multicolumn{1}{l|}{ BM } \\
\hline Anti-image Covarianc PAD & .494 & -.198 & .234 & -.081 & .062 & .094 & -.078 \\
DAU & -.198 & .215 & -.148 & .041 & -.023 & -.165 & -.055 \\
DAK & .234 & -.148 & .390 & -.099 & .085 & .030 & -.129 \\
BHP & -.081 & .041 & -.099 & .223 & -.198 & -.085 & .011 \\
ID & .062 & -.023 & .085 & -.198 & .231 & .075 & -.017 \\
BP & .094 & -.165 & .030 & -.085 & .075 & .391 & -.044 \\
BM & -.078 & -.055 & -.129 & .011 & -.017 & -.044 & .573 \\
\hline Anti-image Correlatio PAD & $.361^{\mathrm{a}}$ & -.607 & .534 & -.245 & .182 & .215 & -.147 \\
DAU & -.607 & $.609^{\mathrm{a}}$ & -.512 & .188 & -.103 & -.569 & -.156 \\
DAK & .534 & -.512 & $.538^{\mathrm{a}}$ & -.336 & .284 & .077 & -.274 \\
BHP & -.245 & .188 & -.336 & $.415^{\mathrm{a}}$ & -.872 & -.286 & .030 \\
ID & .182 & -.103 & .284 & -.872 & $.442^{\mathrm{a}}$ & .251 & -.046 \\
BP & .215 & -.569 & .077 & -.286 & .251 & $.693^{\mathrm{a}}$ & -.093 \\
BM & -.147 & -.156 & -.274 & .030 & -.046 & -.093 & $.885^{\mathrm{a}}$ \\
\hline
\end{tabular}

a. Measures of Sampling Adequacy(MSA)

Berdasarkan hasil anti-image correlation pada tabel 5.2. di atas terlihat korelasi dari masing-masing faktor tersebut bervariasi, ada yang berada di atas 0,5 dan ada dua faktor yang berada di bawah 0,5. Hasil pengujian analisis menunjukkan bahwa variabel Pendapatan Asli Daerah (PAD) memiliki nilai korelasi sebesar 0,361, Dana Alokasi Umum (DAU) sebesar 0,609, Dana ALokasi Khusus (DAK) sebesar 0,538, Dana Bagi Hasil (DBH) sebesar 0,415, Investasi Daerah sebesar 0,442, 


\section{RAMADONA SIMBOLON}

Belanja Pegawai (BP) sebesar 0,693, dan Belanja Modal (BM) sebesar 0,885. Sehingga berdasarkan hasil pengujian dapat disimpulkan bahwa ada 4 faktor yaitu Dana Alokasi Umum (DAU), Dana Alokasi Khusus (DAK), Belanja Pegawai (BP) dan Belanja Modal (BP) adalah valid digunakan sebagai faktor pembentuk Pertumbuhan Ekonomi. Sedangkan faktor PAD, BHP dan ID bukan merupakan faktor pembentuk Pertumbuhan Ekonomi sehingga harus dikeluarkan dalam melakukan analisis selanjutnya.

\subsubsection{Pengujian hipotesis dengan analisis regresi berganda}

Setelah dilakukan pengujian hipotesis menggunakan analisis faktor, pengujian hipotesis dilanjutkan dengan analisis regresi berganda yang terdiri dari uji $\mathrm{F}$ dan uji t. yaitu untuk melihat pengaruh variabel independen terhadap variabel dependen secara bersama-sama dan parsial.

\subsection{Uji F}

Uji F digunakan untuk mengetahui pengaruh variabel independen terhadap variabel dependen secara bersama-sama. Variabel independen dikatakan berpengaruh terhadap variabel independen secara bersama-sama jika nilai $p$-value (pada kolom sig.) lebih kecil dari level of significant yang ditentukan (sebesar $5 \%$ ). Hasil uji $\mathrm{F}$ dapat dilihat pada Tabel 5.3 di bawah ini :

\section{Tabel 5.3. Hasil Uji F}

\begin{tabular}{|c|c|c|c|c|c|c|}
\hline \multicolumn{7}{|c|}{ ANOVA } \\
\hline \multicolumn{2}{|c|}{ Model } & $\begin{array}{l}\text { Sum of } \\
\text { Squares }\end{array}$ & $\mathrm{df}$ & Mean Square & $\mathrm{F}$ & Sig. \\
\hline \multirow[t]{3}{*}{1} & Regression & $6 \mathrm{E}+027$ & 4 & $1.542 \mathrm{E}+027$ & 48.249 & $.000^{\mathrm{a}}$ \\
\hline & Residual & $3 E+027$ & 83 & $3.195 E+025$ & & \\
\hline & Total & $9 \mathrm{E}+027$ & 87 & & & \\
\hline
\end{tabular}

a. Predictors: (Constant), BM, BP, DAK, DAU

b. Dependent Variable: PE

Dari uji $\mathrm{F}$ pada $\alpha=5 \%$ atau 0,05 diperoleh nilai $\mathrm{p}$ value (sig) sebesar 0.000 . Karena nilai probabilitas $(0,000)$ jauh lebih kecil dari 0,05 maka Dana Alokasi Umum, Dana Alokasi Khusus, Belanja Pegawai dan Belanja Modal berpengaruh secara bersama-sama terhadap Pertumbuhan Ekonomi.

\subsection{Uji t}

Uji t digunakan untuk mengetahui pengaruh variabel independen secara parsial terhadap variabel dependen dengan tingkat signifikansi dalam penelitian ini menggunakan alpha $5 \%$ atau 0,05 . Adapun variabel independen dalam penelitian ini adalah DAU (Dana Alokasi Umum), DAK (Dana Alokasi Khusus), BP (Belanja Pegawai) dan BM (Belanja Modal) sedangkan variabel dependen adalah PE (Pertumbuhan Ekonomi). Hasil pengujian hipotesis dengan uji t disajikan dalam Tabel 5.4. berikut ini. 


\section{RAMADONA SIMBOLON}

Tabel. 5.4. Hasil Uji t

Coefficients $^{\mathrm{a}}$

\begin{tabular}{|ll|r|r|r|r|r|}
\hline \multirow{2}{*}{ Model } & \multicolumn{2}{|c|}{$\begin{array}{c}\text { Unstandardized } \\
\text { Coefficients }\end{array}$} & $\begin{array}{c}\text { Standardized } \\
\text { Coefficients }\end{array}$ & & \\
\cline { 2 - 5 } & & \multicolumn{1}{|c|}{$\mathrm{B}$} & Std. Error & \multicolumn{1}{c|}{ Beta } & \multicolumn{1}{c|}{$\mathrm{t}$} & Sig. \\
\hline & (Constant) & $-2 \mathrm{E}+012$ & $1 \mathrm{E}+012$ & & -1.727 & .088 \\
& DAU & 71.520 & 6.410 & 1.144 & 11.158 & .000 \\
& DAK & -395.360 & 57.245 & -.545 & -6.907 & .000 \\
& BP & -21.410 & 8.445 & -.231 & -2.535 & .013 \\
& BM & 11.661 & 10.315 & .089 & 1.130 & .262 \\
\hline
\end{tabular}

a. Dependent Variable: PE

Dari tabel 5.4 di atas, diperoleh hasil untuk masing-masing variabel independen yaitu variabel DAU memiliki nilai p-value (pada kolom Sig.) $0,000<$ 0,05 artinya. Hal tersebut berarti bahwa DAU secara parsial berpengaruh terhadap PE. Variabel DAKmemiliki nilai p-value (pada kolom Sig.) 0,000<0,05. Hal tersebut berarti bahwa DAK secara parsial berpengaruh terhadap PE. Variabel BP memiliki nilai $p$-value (pada kolom Sig.) 0,013<0,05. Hal tersebut berarti bahwa variabel BP secara parsial berpengaruh terhadap PE. Variabel BM memiliki nilai $p$ value (pada kolom Sig.) 0,262 > 0,05. Hal tersebut berarti bahwa variabel BM secara parsial tidak berpengaruh terhadap PE.

\subsection{Uji Koefisien Determinan}

Setelah dilakukan pengujian hipotesis menggunakan analisis faktor, uji $\mathrm{F}$, uji t analisis dilanjutkan dengan uji koefisien determinan. Ringkasan koefisien determinan dapat dilihat pada Tabel 5.5. sebagai berikut.

\section{Tabel Hasil Koefisien Determinan}

\begin{tabular}{|l|r|r|r|r|}
\multicolumn{7}{|c}{ Model Summary } \\
\hline Model & $\mathrm{R}$ & R Square & $\begin{array}{c}\text { Adjusted } \\
\text { R Square }\end{array}$ & $\begin{array}{c}\text { Std. Error of } \\
\text { the Estimate }\end{array}$ \\
\hline 1 & $.836^{\mathrm{a}}$ & .699 & .685 & $5.653 \mathrm{E}+012$ \\
\hline
\end{tabular}

a. Predictors: (Constant), BM, BP, DAK, DAU

Koefisien determinan $\left(R^{2}\right)$ terletak pada tabel model Summary dan tertulis $R$ Square dan sebaiknya menggunakan $R$ Square yang sudah disesuaikan atau tertulis Adjusted $R$ Square karena disesuaikan dengan jumlah variabel independen yang 


\section{RAMADONA SIMBOLON}

digunakan dalam penelitian. Berdasarkan Tabel 5.5. di atas terlihat bahwa nilai koefisien determinan $\left(R^{2}\right)$ yang sudah disesuaikan (Adjusted $R$ Square) adalah sebesar 0,685. Hal ini berarti bahwa 68,5\% variabel dependen (PE) dijelaskan oleh variabel independen (DAK, DAU, BP, BM), dan sisanya sebesar 31,5 \% (100\%$68,5 \%$ ) dijelaskan oleh variabel lain di luar variabel yang digunakan dalam penelitian ini.

\section{PEMBAHASAN}

Hasil analisis faktor menunjukkan bahwa variabel PAD, BHP dan ID tidak dapat digunakan sebagai faktor pembentuk PE sedangkan yang layak digunakan adalah hanya 4(empat) variabel yaitu DAK, DAU, BP dan BM. Hal ini terlihat dari nilai korelasi masing-masing faktor yaitu untuk variabel Pendapatan Asli Daerah (PAD) memiliki nilai korelasi sebesar 0,361, Dana Alokasi Umum (DAU) sebesar 0,609, Dana ALokasi Khusus (DAK) sebesar 0,538, Dana Bagi Hasil (DBH) sebesar 0,415, Investasi Daerah sebesar 0,442, Belanja Pegawai (BP) sebesar 0,693, dan Belanja Modal (BM) sebesar 0,885. Sehingga berdasarkan hasil tersebut bahwa PAD, DBH dan ID tidak dapat digunakan sebagai faktor pembentuk PE.

Hasil penelitian ini tidak mendukung penelitian-penelitian sebelumnya yang dilakukan oleh Joko Waluyo (2007) yang menelit tentang Pertumbuhan Ekonomi dan Ketimpangan Pendapatan antar Propinsi, dan kawasan sejak diberlakunya otonomi daerah di Indonesia (tahun 2001-2005). Metode Penelitian yang digunakan adalah metode ekonometrika persamaan simultan dengan menggunakan data panel antar propinsi. Ketimpangan pendapatan antardaerah didekati dengan menggunakan indeks tertimbang Williamson. Hasil dari penelitian Joko Waluyo (2007) menunjukkan bahwa seluruh variabel yang menjadi variabel penelitian di dalam penelitian ini yaitu pendapatan asli daerah, dana alokasi umum, dana alokasi khusus, dana bagi hasil dan investasi daerah berpengaruh positif signifikan terhadap pertumbuhan ekonomi.

Berdasarkan hal tersebut hasil penelitian ini menunjukkan adanya ketidakkonsistenan dengan penelitian-penelitian sebelumnya dan teori-teori yang ada. Teori menyatakan bahwa semakin tinggi Pendapatan Asli Daerah akan meningkatkan untuk terlaksananya sarana dan prasarana fisik pembangunan sehingga tersedianya pelayanan masyarakat dalam peningkatan pembangunan infrastruktur yang akan berpengaruh terhadap Pertumbuhan Ekonomi. Akses peningkatkan PAD akan mempercepat Pertumbuhan Ekonomi dalam menambah asset seperti peralatan, bangunan, infrastruktur dan harta tetap lainnya.

Hasil analisis faktor yang menunjukkan bahwa PAD, DHP dan ID tidak dapat digunakan sebagai faktor pembentuk pertumbuhan ekonomi pada penelitian ini menggambarkan bahwa PAD dihasilkan lebih banyak hanya dari sektor yang tidak riil yaitu seperti pajak dan bunga. PAD yang dihasilkan dari sektor riil hanya berjumlah sedikit. Hal tersebut menunjukkan bahwa di Kabupaten/Kota Propinsi 


\section{RAMADONA SIMBOLON}

Sumatera Utara masih memiliki lapangan pekerjaan yang sedikit sehingga menimbulkan masih banyaknya pengangguran.

Kedua hasil tersebut juga menunjukkan bahwa kondisi masyarakat di Kabupaten/Kota Propinsi Sumatera Utara yang masih banyak berpendidikan rendah dan memiliki budaya yang malas. Hal tersebut menunjukkan bahwa masyarakat di Kabupaten/Kota Propinsi Sumatera Utara tidak produktif, namun bersifat konsumtif. sehingga berdasarkan hal tersebut masyarakat di Kabupaten/Kota di propinsi sumatera Utara tidak mampu untuk menciptakan lapangan kerja dan pendapatan yang diperolehnya lebih banyak digunakan untuk konsumtif dan tidak digunakan untuk menciptakan lapangan kerja yang akan dapat meningkatkan pendapatan dari sektor riil.

Ketiga, hasil tersebut juga membuktikan bahwa selain konsumtif, masyarakat di Kabupaten/Kota Propinsi Sumatera Utara selain konsumtif juga hanya mampu mengalokasikan pendapatannya ke tabungan dan bukan dengan menciptakan lapangan pekerjaan. Masyarakat Kabupaten/Kota di Propinsi Sumatera Utara berharap dengan menabung akan mendapatkan bunga dan uang yang dimiliki akan lebih aman. hal tersebut juga menunjukkan bahwa masyarakat tersebut masih takut terhadap resiko membuka lapangan pekerjaan sendiri karena takut akan menghadapi kerugian dalam operasionalnya.

Keempat hasil penelitian ini juga menunjukkan bahwa Pemerintah Indonesia masih belum mampu memberikan solusi dalam peningkatan Pendapatan Asli Daerah dari sektor Riil. Pemerintah juga belum mampu memberikan bantuan berupa penyaluran kredit kepada masyarakat yang akan membuka lapangan pekerjaan (usaha) dengan bungan yang rendah. Jikapun ada penyaluran kredit, tetapi penyalurannya tidak tepat sasaran dimana penyaluran tersebut hanya diberikan kepada orang-orang khusus yang belum tentu mampu dan serius dalam membuka lapangan pekerjaan.

Berdasarkan uraian-uraian di atas dapat disimpulkan bahwa Pendapatan Asli Daerah, Dana Bagi Hasil dan Investasi Daerah belum mampu menjadi pembentuk Pertumbuhan Ekonomi. Pemerintah juga belum mapu memberikan solusi yang baik dalam peningkatan Pendapatan Asli Daerah dari Sektor riil, Investasi Daerah yang masih rendah dan belum tepat sasaran dan Dana Bagi Hasil juga masih dalam jumlah yang kecil. Hal tersebut menyebabkan Pendapatan Asli Daerah, Dana Bagi Hasil dan Investasi Daerah belum dapat meningkatkan untuk terlaksananya sarana dan prasarana fisik pembangunan sehingga tersedianya pelayanan masyarakat dalam peningkatan pembangunan infrastruktur yang akan berpengaruh terhadap Pertumbuhan Ekonomi. Selain itu PAD, DHP dan ID juga belum dapat mempercepat Pertumbuhan Ekonomi dalam menambah asset seperti peralatan, bangunan, infrastruktur dan harta tetap lainnya.

Hasil analisis faktor juga menunjukkan bahwa variabel Dana Alokasi Khusus, Dana Alokasi Umum, Belanja Pegawai dan Belanja Modal adalah merupakan faktor pembentuk Pertumbuhan Ekonomi. Hasil tersebut sudah sejalan dengan penelitian- 


\section{RAMADONA SIMBOLON}

penelitian sebelumnya dan teori-teori yang ada. Dana Alokasi Khusus, Dana Alokasi Umum, Belanja Pegawai dan Belanja Modal dapat meningkatkan untuk terlaksananya sarana dan prasarana fisik pembangunan sehingga tersedianya pelayanan masyarakat dalam peningkatan pembangunan infrastruktur yang akan berpengaruh terhadap Pertumbuhan Ekonomi. Selain itu PAD, DHP dan ID juga belum dapat mempercepat Pertumbuhan Ekonomi dalam menambah asset seperti peralatan, bangunan, infrastruktur dan harta tetap lainnya.

Terdapat beberapa kemungkinan untuk menjelaskan hasil tersebut. Pertama, hasil ini membuktikan bahwa masyarakat kabupaten/kota di Propinsi Sumatera Utara masih banyak mengandalkan pendapatan dari gaji. Selain itu masyarakat di kabupaten/kota Propinsi Sumatera Utara juga kebanyakan masih berharap untuk menjadi seorang Pegawai Negeri sipil (PNS) sehingga hanya berharap dari gaji dan tidak mampu untuk menjadikan gaji tersebut lebih produktif lagi yaitu digunakan untuk membuka lapangan pekerjaan (usaha).

Selain itu, hasil tersebut juga menunjukkan bahwa Pemerintah Kabupaten/Kota di Propinsi Sumatera Utara masih banyak berharap dari Dana Alokasi Khusus dan dana Alokasi Umum dan tidak mampu meningkatkan pendapatan dari sektor lain seperti pendapatan dari investasi. Hal tersebut juga menunjukkan bahwa Pemerintah Kabupaten/Kota di Propinsi Sumatera Utara belum memapu meningkatkan pendapatan yang masih memiliki cukup banyak potensi. Pemerintah Kabupaten/Kota Propinsi Sumatera Utara belum mampu menerapkan strategi untuk meningkatkan pendapatannya.

Hasil penelitian berdasarkan hasil uji F diperoleh bahwa Dana Alokasi Khusus, Dana Alokasi Umum, Belanja Pegawai dan Belanja Modal secara simultan berpengaruh terhadap Pertumbuhan Ekonomi. Hasil tersebut sudah sejalan dengan penelitian-penelitian sebelumnya dan teori-teori yang ada yang menyatakan bahwa Dana Alokasi Khusus, Dana Alokasi Umum, Belanja Pegawai dan Belanja Modal dapat meningkatkan untuk terlaksananya sarana dan prasarana fisik pembangunan sehingga tersedianya pelayanan masyarakat dalam peningkatan pembangunan infrastruktur yang akan berpengaruh terhadap Pertumbuhan Ekonomi. Selain itu PAD, DHP dan ID juga belum dapat mempercepat Pertumbuhan Ekonomi dalam menambah asset seperti peralatan, bangunan, infrastruktur dan harta tetap lainnya.

Selanjutnya berdasarkan hasil uji t diperoleh bahwa Dana Alokasi Khusus, Dana Alokasi Umum dan Belanja Pegawai secara parsial berpengaruh terhadap Pertumbuhan ekonomi sedangkan Belanja Modal secara parsial tidak berpengaruh terhadap Pertumbuhan Ekonomi. Hasil tersebut sudah sejalan dengan penelitianpenelitian sebelumnya dan teori-teori yang ada kecuali untuk Belanja Modal yang tidak berpengaruh terhadap Pertumbuhan Ekonomi. Hal ini menunjukkan bahwa infrastruktur yang diperoleh melalui Belanja Modal belum dapat dirasakan secara langsung untuk meningkatkan pendapatan masyarakat Kabupaten/Kota Propinsi Sumatera Utara. Masyarakat Kabupaten/Kota Propinsi Sumatera Utara masih belum mampu memanfaatkan infrastruktur dan fasilitas-fasilitas yang disediakan oleh 


\section{RAMADONA SIMBOLON}

Pemerintah. Selain itu Pemerintah juga belum mampu mengarahkan masyakat untuk memanfaatkan infrastruktur dan fasilitas yang ada. Infrastruktur yang disediakan Pemerintah juga tidak bersifat produktif dan lebih banyak mengarah pada proyekproyek yang menguntungkan diri pribadi.

\section{PENUTUP}

Berdasarkan analisis dan pembahasan yang telah dikemukakan sebelumnya maka dapat ditarik kesimpulan sebagai berikut :

1. Hasil pengujian hipotesis dengan menggunakan analisis faktor menunjukkan bahwa PAD, DHP dan ID tidak dapat digunakan sebagai faktor pembentuk Pertumbuhan Ekonomi. Hasil penelitian ini tidak sejalan dengan penelitian terdahulu yang dilakukan oleh Joko Waluyo (2007) dan teori.

2. Hasil pengujian hipotesis dengan menggunakan analisis faktor juga menunjukkan bahwa DAK, DAU, BP dan BM dapat digunakan sebagai faktor pembentuk Pertumbuhan Ekonomi. Hasil penelitian ini sejalan dengan penelitian terdahulu yang dilakukan oleh Joko Waluyo (2007) dan teori.

3. Hasil pengujian hipotesis dengan menggunakan uji $\mathrm{F}$ menunjukkan bahwa DAK, DAU, BP dan BM secara simultan berpengaruh terhadap Pertumbuhan Ekonomi. Hasil penelitian ini sejalan dengan penelitian sebelumnya dan teori.

4. Hasil pengujian hipotesis dengan menggunakan uji t menunjukkan bahwa DAK, DAU, BP secara parsial berpengaruh terhadap Pertumbuhan Ekonomi. Hasil penelitian ini sejalan dengan penelitian sebelumnya dan teori kecuali untuk Belanja Modal yang secara parsial tidak berpengaruh terhadap pertumbuhan ekonomi..

5. Hasil koefisien determinan menunjukkan bahwa diluar variabel DAK, DAU, BP dan BM masih terdapat variabel lain yang mempengaruhi pertumbuhan ekonomi.

6. Hasil penelitian ini hanya dapat dijadikan analisis pada obyek penelitian yang terbatas pada kabupaten/kota Propinsi Sumatera Utara, sehingga penelitian ini tidak dapat melihat faktor-faktor yang mempengaruhi pertumbuhan ekonomi di Propinsi lain yang ada di Indonesia.

7. Variabel yang digunakan untuk mengukur faktor-faktor yang mempengaruhi pertumbuhan ekonomi pada penelitian ini, hanya sebatas PAD, DAU, DAK, DHP, BP, BM dan ID, sehingga masih banyak kemungkinan faktor lain yang dapat mempengaruhi pertumbuhan ekonomi.

8. Jumlah periode pengamatan penelitian ini adalah empat tahun (periode 20052008). Ini menyebabkan data-data pada periode 2009-2010 tidak dijadikan sampel pada penelitian ini. Sementara berdasarkan informasi-informasi yang ada bahwa pada periode 2009-2010 terjadi perubahan pertumbuhan ekonomi. 


\section{RAMADONA SIMBOLON}

\section{DAFTAR PUSTAKA}

Agung Nugroho, Bambang. 2005. Strategi Jitu Memilih Metode Statistik Penelitian dengan Spss. Yogyakarta: Penerbit ANDI.

Bastian, Indra (a). 2006. Akuntansi Sektor Publik; Suatu Pengantar. Jakarta: Erlangga.

Bastian, Indra (b). 2001. Manual Akuntansi Keuangan Pemerintah Daerah. Yogyakarta: PPA FE UGM.

Badan Pusat Statistik. 2007. Data Statistik BPS. Medan: BPS Pusat Pemerintah Provinsi Sumatera Utara.

Ghozali, Imam. 2005. Aplikasi Analisis Multivariate dengan Program SPSS. Semarang: Badan Penerbit Universitas Diponegoro.

Gujatari, Damodar.2003. Ekomometrika Dasar: Edisi Keenam, Jakarta. Erlangga

Halim, Abdul. 2002. Akuntansi Sektor Publik: Akuntansi Keuangan Daerah. Jakarta: Salemba Empat.

Halim, Abdul. 2004. Akuntansi Sektor Publik: Akuntansi Keuangan Daerah, Edisi Revisi. Jakarta: Salemba Empat.

Hamzah, Ardi. 2009. Pengaruh Pendapatan Asli Daerah, Dana Perimbangan dan Belanja Publik terhadap Pertumbuhan Ekonomi, Kemiskinan, dan Pengangguran: Pendekatan Analisis Jalur. (Studi Pada 38 Kota/Kabupaten di Propinsi Jawa Timur Periode 2001-2006). Jurnal: Balitbang Depdagri.

Harahap, Sofyan Syafri. 2007. Teori Akuntansi, Edisi Revisi. Jakarta: PT Raja Grafindo Persada.

Isdijoso, Brahmantio, 2002. Analisis Kebijakan Fiskal pada Era Otonomi Daerah (Studi Kasus: Sektor Pendidikan di Kota Surakarta), Kajian Ekonomi Dan Keuangan Vol. 6 No. 1.

Indriantoro, Nur dan Bambang Supomo. 2002. Metodologi Penelitian Bisnis untuk Akuntansi dan Manajemen.Yogyakarta: BPFE Universitas Gajah Mada.

Kuncoro, Mudrajat.2003. Metode Riset untuk Bisnis dan Ekonomi, Erlangga, Jakarta.

Rizky Fitriyanti, Ismi; Pratolo, Suryo. 2009. Pengaruh Pendapatan Asli Daerah dan Belanja Pembangunan terhadap Rasio Kemandirian dan Pertumbuhan Ekonomi (Studi pada Kota, Kabupaten dan Provinsi di DIY). Jurnal: Balitbang Depdagri.

Rokhmawati, Anita. 2009. Pengaruh Belanja Modal dan PAD terhadap Pertumbuhan Ekonomi Daerah (Studi pada Kabupaten dan Kota di Jawa Timur). UMN Yogyakarta: Jurnal. 
Sugiyono. 2007. Metode Penelitian Bisnis. Bandung: Penerbit Alfabeta.

Syahyunan, Iskandar, dkk. 2008. Analisis Data Penelitian. Medan: USU Press.

Fakultas Ekonomi Universitas Sumatera Utara, Jurusan Akuntansi, 2004. Buku Petunjuk Teknis Penulisan Proposal Penelitian dan Penulisan Skripsi, Medan. USU Press.

Waluyo, Joko. 2007. Dampak Desentralisasi Fiskal terhadap Pertumbuhan Ekonomi dan Ketimpangan Pendapatan antar daerah di Indonesia.FE UI: Tesis.

Permendagri 13 Tahun 2006 tentang Belanja Langsung dan Belanja Tidak Langsung.

Undang-undang No. 32 Tahun 2004 tentang Pemerintah Daerah. Yogyakarta: UII Press.

Undang-undang No. 33 Tahun 2004 tentang Perimbangan Keuangan antara Pemerintah Pusat dan Pemerintah Daerah. Yogyakarta: UII Press. 